\title{
Effectiveness of BME Strategy in Improving Writing Skills among Low Proficiency English Language Learners
}

\author{
MANESHA KAUR A/P RAJENDRA SINGH \\ Sekolah Menengah Kebangsaan St Patrick \\ manesha_pretti@hotmail.com
}

\begin{abstract}
This study investigates the effects of Beginning-Middle-End (BME) strategy on the improvement of English writing skills among the lower proficiency language learners in a secondary school located in the state of Kedah. Utilising the BME within language classroom is seen as a valuable approach which offers assistance to lower proficient learners to progress in their English writing skills. Writing is a common issue affecting most second language learners (ESL) as these would lead the learners to lose motivation in learning writing in English. Although writing is without doubt the most challenging proficiency to be acquired, it is a vital skill to measure learners' level of proficiency in English language. The objective of this study is to assess the effectiveness of BME strategy in improving writing skills among secondary school learners. This quasiexperimental study was conducted within a 4 month period where twenty seven samples were given one writing lesson per week involving an in-depth BME intervention. Data was collected via the pre-and post-test. The post-test scores indicate that learners have developed better writing skill with the intervention of BME strategy. The findings identified that participants improved significantly in their writing skills. Implementation of BME to improve writing skill is a worthy strategy which ought to be adopted in teaching lower proficiency English language learners.

Keywords: BME Strategy; English Language Writing Skills; Secondary school; Low Proficiency English Language Learners
\end{abstract}

Published online: October 2020

To cite this article: Singh, M. K. R. (2020). Effectiveness of BME Strategy in Improving Writing Skills among Low Proficiency English Language Learners. International Journal of Language, Literacy and Translation 3(2), 32-45. https://doi.org/10.36777/ijollt2020.3.2.037

To link to this article: https://doi.org/10.36777/ijollt2020.3.2.037

This work is licensed under the terms of the Creative Commons Attribution (CC BY) (https://creativecommons.org/licenses/by/4.0/). 


\section{INTRODUCTION}

Writing is reflected to be a critical means of communication through which humans are able to not only express their thoughts but also discover the thoughts of others. It is deemed to be pride of the human mind, as it is the greatest production of human thought. According to Saed and Al-Omari (2014), composition makes a difference in moving forward all the other aptitudes of listening, speaking and reading as they are all interconnected. Writing fortifies consideration, compels learners to concentrate and organize thoughts and develop capacities to summarise, analyse, and criticise. Maghsoudi and Haririran (2013) argues that writing accentuates consistent learning, considering and doing reflection within the English Language.

Oral and written communication are fundamental as these allow people to interrelate with each other. Graham (2006) states writing as a picked up noteworthy significance and has got to be a vital tool for teachers to guarantee that learners are successful in their education.

It is the teachers' responsibility to assist learners cope with difficulties in the writing skills. This study is one of the attempt made by researcher to overcome the problem of learning writing. Based on the researcher's observation, it was discovered that the issue learners' experience, other than the language barrier, was organising and developing ideas. Researcher found the lack of interest has made it challenging for learners to accomplish the English writing task. Learners lose interest when they are unable to develop ideas or construct sentences. A large number of learners would either copy available essays from various source or have a few words to write whenever they are asked to write a composition. This is known as product approach in teaching writing skill. Steele (2004) said learners would first consider example of essays after the focus of the class is highlighted. For example, consider a formal letter writing task, learner's consideration may be drawn to the significance of paragraphing and the language utilised to create the formal request. However, the researcher believes this approach is not beneficial for learners to utilise during writing lesson. Learners are not exposed to critical thinking where they should be allowed to develop ideas and construct sentences. This could result in lack of ideas among learners and eventually lose motivation to attempt the writing task.

Therefore, the researcher believes that learners should be allowed to use process-approach in learning writing skills. In this approach, with the intervention of BME strategy, learners are trained to brainstorm, develop, organise ideas construct cohesive sentences correctly. While it is true, Nunan (2001) explains how unalike process-approach is from the traditional product-oriented approach. Although the product approach stresses on writing tasks in which learners copy, change and reproduce teacher supplied essays, the process-approach focuses on the elaborate stages involved in writing task. The aim of product writing is an error-free clear writing. Process writing accepts that a writer will be able to have excellence by producing, reflecting, discussing and editing written drafts.

BME

BME defined as Beginning, Middle and End is a strategy designed by the researcher to aid low proficiency learners overcome writing problems. Writing is a difficult task which involves many sub-skills like organizing and developing ideas, choosing the right vocabulary and constructing cohesive sentences. As mentioned by Dunsmuir et al. (2014), the key domains of writing replicate the main attention of developing ideas (rhetorical skills), vocabulary, forming sentences and grammar, spelling, punctuation and handwriting (mechanics). Some inexperienced learners might lack these skill and some 
only partly achieve at writing skills, therefore by applying useful writing strategy, learners will be able to organise ideas efficiently and cohesively.

Learners who seldom score well in their compositions may find writing difficult and frightening. Additionally, students who have received unpleasant analysis, discouraging input and grades may feel less certain when composing written essays. These students may accept the notion that they are simply incapable at composing. Lau and Lee (2012) stated that interactive learning environment encourages learners in developing positive learning behaviours in the education process.

Thus, the researcher came up with the BME strategy to help learners overcome their writing problems. The researcher believes that teachers should understand the need and interest of learners and try to adopt varies strategies to improve their learner's English writing skills. For this purpose, the researcher has to shift from the traditional methods of teaching writing where learners were never given the opportunity to brainstorm for ideas, to the modern approach of BME.

The researcher believes that process approach theory plays a vital role in enhancing learners writing skills through BME strategy. Kroll (2001, p.221) states drafting and receiving comments on learners draft, be it frompeer or the teacher is one of the necessary step in the process-approach. By using this approach, especially in situations when learners are given the opportunity to develop and organise ideas, the teacher is able to create an effective opportunity for learners to learn writing skills by using BME strategy. The teacher allows learners to write independently and creatively using BME strategy. Consequently, process-approach plays an important role in this study as it helps learners improve writing skills in English classroom using BME strategy.

As mentioned by Zhao (2015) in a study, writing is difficult as it requires a higher level of cognitive skills; gathering, organising information, sequencing and expressing information or ideas into written draft for editing. BME help learners to brainstorm, plan and organise ideas effectively during writing. BME is used as a tool before learners are able to write a complete essay. This paper emphasise on the techniques of teaching BME to improve learners writing skill. In this regard, the researcher has adopted an innovative teaching technique to actively involve learners in their writing tasks. On the other hand, learners are required follow the guidelines provided by the researcher and participate in pair or group activities. Learners are encouraged to spend more time on writing as it is challenging skill for them to acquire and master. Hence, they are encouraged to put effort into learning the necessary writing skills by choosing the topics of their own interest.

According to Jusun and Md Yunus (2010), writing is the most challenging skill in an ESL classroom. It is a known fact that writing is a very important skill and teachers have to facilitate the proper development of this particular skill among the English language learners. Hence, English teachers should motivate and encourage learners to utilise the BME strategy in classrooms. When the learners are highly motivated, they actively participate in the given tasks and will attempt to produce excellent products. While selecting the topics, teachers have to consider learners interest and need of learners so that they would enjoy the lesson.

It is also very important for the teachers to understand the common difficulty faced by learners in regard to writing. When giving a writing task to learners, they have to encourage and facilitate learners on how to express ideas and organise the given task using the BME strategy. Teachers have to guide the learners during the stages of writing involving various sub-skills. As such, teachers have to provide sufficient guidance and encouragement to motivate learners. 


\section{STATEMENT OF PROBLEM}

Based on the researcher's reflection, English writing skills of the learners in the selected school is inadequate. This is further substantiated by the low scores and poor execution of the apprentices in the English language test. One of the learners' weaknesses which contributes towards poor performance in writing the planning skill. Berman and Cheng (2001) stated that mostly non-native speakers of English language face difficulties in productive skills of writing and speaking rather than listening and reading. Therefore, this failure has led the learners to face complications in accepting and following the writing activities conducted in the classroom.

The 2004 School Certificate Examination Report on English Language 2 (MOE, 2005), revealed that most of the candidates have yet to master writing skill. Melor and Chan (2016) also indicated that writing is rather challenging because not only is it interrelated to different language skills but it also requires comprehensive knowledge of grammar, suitable choice of words or phrases, writing mechanics, organisational skills and writing styles. This study expected to help ESL educators as the BME strategy can be an instructional tool to assist educators in teaching writing.

\section{OBJECTIVE OF THE STUDY}

The main purpose of this case study is to investigate the effectiveness of BME strategy in improving writing skills among low proficiency English language learners. This case study strongly believes that learners will improve in writing skills if they are allowed to plan, develop and organise ideas.

\section{SIGNIFICANCE OF THE STUDY}

This study will make a substantial contribution to the English language development of the Form Three learners. Findings of the study will be able to assist language teachers to develop teaching activities which will enhance the learners writing skills. Learners will benefit by taking responsibility of their education and ultimately producing an efficient written product in English classroom. Aside from helping learners secure fundamental writing skills, the BME strategy improves learners' understanding and critical thinking capacity.

The success of BME strategy in writing skills would also assist the educators to upgrade their teaching pedagogy.

\section{THEORETICAL PERSPECTIVES}

Graham Stanley (1993) argues that process-approach writing as an imaginative act which requires time and tremendous feedback to be completed well. In process writing, the teacher moves away from setting student's writing topic and receives the finished product for correction without any intervention in the writing process itself. Vanessa Steele explains process-approach as concentrating more on the diverse classroom activities which inspire the improvement of language use; brainstorming, group discussion and re-writing. Nunan (1991) undoubtedly states that process-approach emphasise on steps involved in creating a piece of 
work and the fact that no text can be perfect, but that a writer will get closer to perfection by producing, reflecting, discussing and reworking drafts. Fowler (1989) concedes that process writing as a response to product-approach, as it meets the need to equal the writing processes inherent in writing in one's mother tongue, and subsequently let learners express themselves better as individuals.

Graham and Sandmel (2011) pointed out based on meta-analysis of process writing approach, that the instructional method is best implemented broadly in any effort to reform writing practices. Here, the learners are stimulated by educators through planning, drafting and revising. According to Graham and Sandmel (2011) process-approach provides platform for addressing needs of individual student and inspiration for writing can be improved through cooperation, responsibility, personal attention and a positive learning environment (p.397). Clearly, process-approach establishes a supportive environment in which learners are the active writers in creating their own writing.

\section{REVIEW OF RELATED STUDIES}

Writing skills considered the most challenging ability in English language. As writing is a difficult task and it demands both cognitive analysis as well as linguistic synthesis. The educators should motivate and inspire the learners to improve their writing skills. Richards and Schmidt (2002) assert, "Writing is regarded as a result of complex stages of planning, drafting, reviewing and revising". Troyka (2010) adds the purposes of writing is to allow writers to communicate by providing information, encourage readers and create fictional work.

Teaching writing is believed to be most difficult for English language educators and additionally challenging for learners to show signs of improvement. These incorporate skills like spelling, grammar, sentence structure, organisation and coherency. Rao (2019) states that educators should understand learners' level and try to adopt relevant teaching strategies that are more suitable for that particular set of learners. Tasks selected should be simple and familiar to the learners and educators should create an interest among the learners. Thus, educators should constantly think of alternative methods, techniques and approaches to present in classrooms. "ESL learners have to pay attention and emphasise on writing skills. As a result, writing becomes manageable for the learners and they learn it with interest and it will be very useful for attaining good results" (Rao, 2019). As Rao (2017a) asserts, "The educators have to make learners understand the techniques of writing in English and demonstrate by giving some important and interesting topics as examples. While teaching the writing skills in the learners' environment, the educators have to choose topics that are easier and interesting so the learners would concentrate more on their learning. Therefore, educators should take the learners' interests and needs into consideration to increase learners' involvement in the given task". Therefore, the educators should motivate the ESL learners towards learning the techniques of writing as a means to develop learners' skill.

Damian and Yunus (2016) states out of all the language skills, writing is observed to be the most challenging both by learners and the educators, yet it is one of the most important language skills. According to Richards and Renandya (2002), the most difficult skill for second language learners (L2) to comprehend is writing. Learners need to generate, organise and translate these ideas into readable text which can be overwhelming for learners. Even though at present, most of written communication takes place electronically, the learners are still required to produce handwritten answers during exams. 


\section{RESEARCH DESIGN}

This case study involves only one secondary school located in Kulim, Kedah. This study investigates the effects of Beginning-Middle-End (BME) strategy in developing and improving English writing skills among low proficiency learners. By selecting one group of learners from one particular school, it allows the researcher to focus closely to the effectiveness of the proposed BME strategy. Merriam (1988, p. 23) states a case study research seeks to understand specific issues of practice through a detailed examination of specific group, a particular organization, or a selected activity.

The population of learners in the selected school is about 210 in total. Given the small sample size, no control group was used in this study. This qualitative case study utilises a quasi-experimental design involving pre- and post-test. The researcher measures scores before and after following the BME intervention then compares the difference between preand post-test scores.

The one group pre-test and post-test design is defined as:

$(\mathrm{O} 1 \mathrm{X} \mathrm{O} 2)$

\section{O1 : Pre test \\ X : BME Strategy \\ $\mathrm{O} 2$ : Post test}

Data collected in pre- and post-test are in form of scores based on the writing assessment scale. Independent Sample T-Test is utilised to understand significant difference between the means of pre- and post-test in this study.

\section{RESEARCH PROCEDURE}

A weekly research schedule is used as guide for the study (refer to Appendix 1). On the first week, pre-test was carried out to gauge learners writing ability before BME strategy was implemented. On the second week, teacher introduces BME in classroom and learners are exposed to the use BME strategy before writing a complete composition. The teacher explains each section clearly for learner's to understand and how to use BME in developing, planning and organising ideas. Writing exercise was carried once a week in the English classroom.

On week four, teacher chose to stimulate ideas from the learners by questioning and encouraging them to share ideas, discuss with peers and this will help learners construct sentences easily. After learners finished writing their ideas, and organising their ideas into BME accordingly, teacher will allow learners to write three paragraphs. Teacher will facilitate learners by giving appropriate comments and feedback. As Earl and Zimmerman (2003) and Karatay (2011) pointed out the initial stage of writing includes editing and revising. By the seventh week, learners are allowed to use BME sstrategy independently. Teacher will closely monitor the progress and observe each learners work.

Learners will take approximately a few weeks to get familiar with the BME strategy. By the ninth week, learners build confidence and are able to use BME sstrategy in composing writing. From week two till week fifteen, BME strategy has been used as an intervention in the English language classroom. In short, learners were exposed to the BME strategy for a total of fourteen weeks. 
On Week sixteen, learners were given a post-test containing the exact content and structure of the pre-test. Researcher performed an analysis through the comparison of the pretest scores with the post-test scores on week seventeen.

\section{SAMPLING}

A purposive sampling method, classified as selective or subjective was used to carry out this study. It is also known as a type of non-probability sampling technique. Non-probability sampling emphasises on sampling techniques where samples are studied based on the judgement of the researcher. The aim of purposive sampling is to focus on particular characteristics of a population that are of interest who are able to response research questions (Creswell, 1998).

Purposive sampling was used as Form 3 learners were having problem in writing and constructing sentences correctly. These learners are combination of two different ability of intermediate and pre-intermediate level in English.

\section{PARTICIPANTS}

The sample of the study comprises of twenty seven Form 3 students from a secondary school in Kulim, Kedah. This is a small school with total of only 210 students. The researcher chose to work with a small sample of learners to study the effectiveness of BME strategy in-depth. The school authorities have confirmed that majority of the students are from a low income family and these students seldom attempt tasks as they have no interest to improve their English language skill.

\section{INSTRUMENT}

The instruments utilised in this study include a pre- and post-test, 10 lesson plans of writing exercise and a writing scale which is adopted from the Malaysian Ministry of Education.

\section{PRE- AND POST-TEST}

In order to assess learners' writing capabilities before and after the implementation of the BME, writing tests were carried out. Pre-test was carried out at the beginning of the first semester of school year and post-test was carried out at the end of the same semester. Preand post-tests play a crucial role in the research design and to check the effects of random samples on the selected measure (Robson, 2002). The variances among learners in between the two tests may possibly benefit in terms of evaluating the effectiveness of the BME strategy.

\section{WRITING ASSESSMENT SCALE}

The writing assessment scale utilised for this case study was constructed by the Ministry of Education in respect to the specific situations and capacities recorded in the Course of Study by the Ministry of Education.

The construction of the writing tests were revised from the Pentaksiran Pelajar Tingkatan Tiga (PT3) and the lower secondary national examination of English.

The writing assessment scale covers all parts of writing and is divided into four subscales: content, language, organisation and communication achievement. The scales analyse 
learners' strengths and weaknesses when engaging in writing tasks and form an impression of learners' preparedness to sit for the written examination.

\section{LESSON PLAN}

A series of ten task based lesson plans were used as an instrument. In conducting the research, the researcher followed the English syllabus thoroughly and lessons were conducted once a week. Duration was 80 minutes ( $2 \times 40$ minutes) for each lesson. BME strategy was introduced to learners after collecting the pre-test data. Below is an example of a lesson plan carried out during this study.

Table 1

Lesson Plan Form 3

\begin{tabular}{|c|c|}
\hline Date & 6.02 .2018 \\
\hline Form & 3 Setia \\
\hline Time & 4.10-5.20pm (80 minutes) \\
\hline Topic & Knowing Me, Knowing You. \\
\hline Theme & Festival \\
\hline Proficiency Level & Pre- Intermediate \\
\hline Learning Outcomes & $\begin{array}{l}\text { 1. Produce a draft of two or more } \\
\text { paragraphs and modify this } \\
\text { independently. } \\
\text { 2. Spell highly frequent words accurately } \\
\text { in independent writing. } \\
\text { 3. Organise, sequence and develop ideas. }\end{array}$ \\
\hline Objectives & $\begin{array}{l}\text { Students will be able to: } \\
\text { 1. Produce a draft of two paragraphs } \\
\text { using BME strategy. } \\
\text { 2. Spell linking words accurately. } \\
\text { 3. Organise, sequence and develop ideas } \\
\text { on familiar topics. }\end{array}$ \\
\hline $\begin{array}{l}\text { Lesson outline } \\
\text { Pre lesson }\end{array}$ & $\begin{array}{l}\text { 1. Students play a game to review linking } \\
\text { words and phrases. }\end{array}$ \\
\hline Lesson delivery & $\begin{array}{l}\text { 2. Students are reminded to plan before } \\
\text { they begin writing. } \\
\text { 3. Teacher explains BME? (Beginning, } \\
\text { Middle and End) } \\
\text { 4. Students are given worksheets and } \\
\text { coloured papers. } \\
\text { 5. Students read the question and linking } \\
\text { words. } \\
\text { 6. Students are divided into } 4 \text { groups. } \\
\text { 7. In groups students discuss and } \\
\text { brainstorm ideas. } \\
\text { 8. Students share ideas with the class. } \\
\text { 9. In groups, students create BME for the } \\
\text { given questions. } \\
\text { 10. Students present BME in class. } \\
\text { 11. Students give feedback on the }\end{array}$ \\
\hline
\end{tabular}


presentation.

12. Students write a complete essay using BME as guideline.

Reflection

1. Students are able to organise, sequence and develop ideas using BME strategy.

2. Students are able to produce a draft of two paragraphs.

\section{DATA COLLECTION}

In collecting the pre- and post- data, researcher applied the measurement technique to gauge the effectiveness of BME strategy in developing writing skills among less proficient learners. Procedures of data collection are:

a) A pre-test was carried out before the start of treatment and scores were given based on fluency, language accuracy, personal response and pronunciation.

b) BME intervention was conducted for 4 months.

c) Students sit for post-test after the BME intervention.

On the initial day of the study, students were given pre-test of 120 word essay for 40 minutes. After ten weeks of BME lessons, students were given a post-test with a similar manner of essay.

\section{DATA ANALYSIS}

Data were gathered in scores based on the writing assessment scale. The data were analysed using SPSS, descriptive statistics (mean scores and standard deviations). An independent sample T-test was utilised as part of the study. Results were inferred according to the level of significance indicated based on the alpha value of $p=<0.05$ (the ninety-five percent level of confidence). If the probability value is less than the specified alpha value, then the observed $\mathrm{t}$-value is significant. The 95 per cent confidence interval indicates the interval specified will contain the true difference between the population means. This indicates that the null hypotheses can be rejected (Coakes \& Steed, 2003).

In the current study, the independent sample t-test were done to analyse the mean assessments of pre- and post-test of writing abilities.

\section{FINDINGS}

The analysis for this research is based on an independent sample t-test. An independent sample t-test is used to identify significant difference between the means of the pre- and posttest.

Table 2

Independent Sample T-Test

Group Statistics

\begin{tabular}{llllll}
\hline & Group & $\mathrm{N}$ & Mean & Std. Deviation & Std. Error Mean \\
\hline Score & 1 & 27 & 11.30 & 2.383 & .459 \\
\hline
\end{tabular}




\begin{tabular}{lllll}
\hline 2 & 27 & 19.93 & 3.605 & .694 \\
\hline
\end{tabular}

It can be noted that there is difference between the mean of the pre-test (11.30) and posttest mean (19.93). There is a difference of 8.63 points between these two tests. It cclearly indicates the students' writing skills have increased significantly after the BME intervention. The pre-test has a lower mean compared to the post-test $(11.30<19.93)$, which indicates that learners have improved their writing skills. The pre-test standard deviation is 2.383 and posttest standard deviation is 3.605 .

Table 3

Independent Sample T-Test

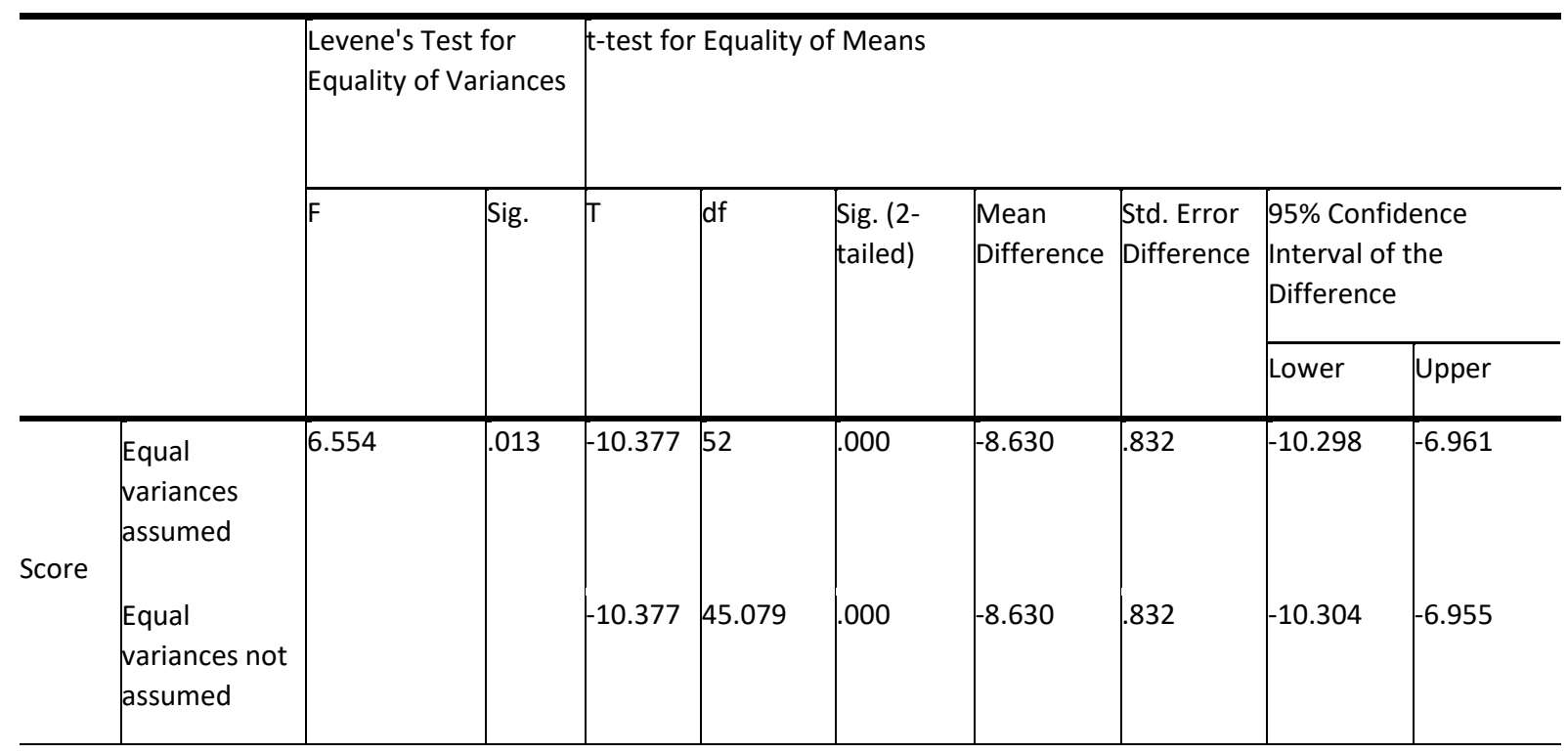

An independent sample t-test was piloted to compare the pre- and post-test score. There is a significant difference in the pre-test scores (mean $=11.30$, sstandard deviation $=2.383$ ) and as for the experimental group (mean=19.93, sstandard deviation $=3.605)$ conditions; $t(52)=$ $-10.377, \mathrm{p}=.000$. Thus, $\mathrm{t}$-test must refer to second row, according to the statement of hypothesis by using t-test on the level of significant $\mathrm{a}=0.05$ and degree of freedom $=52, \mathrm{t}$ score $(\mathrm{p})$ which is $0.000<0.005$. The post-test score results indicates improved accomplishment from the students in contrast with the pre-test. Consequently, the null hypothesis is rejected. It tends to be reasoned that there is a huge difference between pre-test scores and post-test scores.

\section{DISCUSSION}

After completing this study, the researcher concludes that BME sstrategy could improve student's performance in English writing ability. This finding is supported by Rao (2019) who states, "The teachers should always try to understand student's level and try to adopt suitable teaching strategies of improving their writing skills." 
The mean score of post-test was higher than of the pre-test $(11.30>19.93)$. It can be concluded that improvement of writing ability was due to the effectiveness of BME intervention.

Finally, based on t-test analysis, obtained t-test score (-10.377) was higher than the critical score at the level of significance 0.05 that is 1.96 , which proved that alternative hypothesis of this study is accepted, and the null hypothesis is rejected. It indicates the effectiveness of BME strategy on learners' performance in writing skills. These findings also concur with Lau and Lee (2012) that interactive learning environment helps students to develop positive learning behaviours.

Established on the findings of this research, it can be asserted that the BME strategy is critical to create situation-based activities that offer students opportunity to discuss and organise their writing. Based on the research findings and discussions as above, it can be concluded that most of the students perceive BME as an effective strategy in helping them plan, develop and organise ideas to write better.

\section{LIMITATIONS}

A few factors contributed to limitation of the study. Firstly, this is a quasi-experimental study that involves twenty seven samples from a secondary school in Kedah. Hence, the researcher could not use control group in this study due to the population of the learners and this has restricted researcher's finding to only one group of students with poor academic achievement. This study was also limited to one academic semester and dealt with time restrictions due to monthly examination, sports day and public holiday.

\section{RECOMMENDATION}

Although the present study proposes the effectiveness of BME sstrategy on secondary school students, there are some extent which needs to be studied further. It is recommended that future research reflect on having a larger sample of study involving multiple schools. In the future, English teachers could use BME strategy to help intermediate or advance learners in writing skills.

\section{CONCLUSION}

This study shows the positive effects of BME strategy on learners' writing abilities. Learners not only progress in writing but also in building sentences. As an outcome, BME strategy supports learners' certainty level, particularly among pre- intermediate learners to learn and create social relationships. In general, teaching writing utilising the BME strategy is acceptable and a valuable technique to assist capable students in writing skill.

\section{Appendix 1}

Table 4

Weekly research schedule

Week Description

Week $1 \quad$ Pre-test was conducted 


\begin{tabular}{ll}
\hline Week 2 & Intervention using BME \\
\hline Week 3 & Intervention using BME \\
\hline Week 4 & Intervention using BME \\
\hline Week 5 & Intervention using BME \\
\hline Week 6 & Intervention using BME \\
\hline Week 7 & Intervention using BME \\
\hline Week 8 & Intervention using BME \\
\hline Week 9 & Intervention using BME \\
Week 10 & Intervention using BME \\
Week 11 & Intervention using BME \\
Week 12 & Intervention using BME \\
Week 13 & \begin{tabular}{l} 
Intervention using BME \\
\hline Week 14
\end{tabular} \\
\hline Week 15 & Intervention using BME \\
\hline Week 16 & Post-test was conducted \\
\hline Week 17 & $\begin{array}{l}\text { compare the pre- and the } \\
\text { post- test results }\end{array}$ \\
\hline
\end{tabular}

\section{REFERENCES}

Berman, R, \& Cheng, L. (2001). English academic language skills: Perceived difficulties by undergraduate and graduate students, and their academic achievement. Canadian Journal of Applied Linguistics, 4(1-2). 25-40.

Coakes, S. J. \& Steed, L. G. (2003). SPSS: Analysis without anguish. Australia: John Wiley.

Cresswell, J. W. (1998). Qualitative inquiry and Research Design. Choosing Among The five traditions. Sage Publications, CA: Thousand Oaks

Damian, K., \& Yunus, M. M. (2016). The effectiveness of using sentence makers in improving writing performance among pupils in Lubok Antu rural schools. International Conference on Education, 1, 469-475.

Daud, N. S. M., Daud, N. M., \& Kassim, N. L. A. (2016). Second language writing anxiety: Cause or effect. Malaysian Journal of ELT Research, 1(1), 1-19.

Dunsmuir, S., Kyriacou, M., Batuwitage, S., Hinson, E., Ingram, V., \& O'Sullivan, S. (2014). An evaluation of the Writing Assessment Measure (WAM) for children's narrative writing. Assessing Writing, 23, 1-18. https://doi.org/10.1016/j.asw.2014.08.001

Earl, C. B., \& Zimmerman, C. (2003). The reading/writing connection. New York: Longman

Flower, L. (1985). Problem-solving strategies for writing (2nd ed.). San Diego, Harcourt: Brace Jovanich.

Fowler, W. S. (1989). Progressive writing skills. Surry: Thomas Nelson and Sons Ltd. 
Ghabool. N., Mariadass. M., \& Kashef, S. H. (2012). Investigating Malaysian ESL students' writing problems on conventions, punctuation, and language use at secondary school level. Journal of Studies in Education, 2(3), 130-143. https://doi.org/10.5296/jse.v2i3.1892

Graham, S. (1993). Process writing, British Council, Barcelona.

Graham, S. (2006). Strategy Instruction and the Teaching of Writing: A Meta-Analysis. In C. A. MacArthur, S. Graham, \& J. Fitzgerald (Eds.), Handbook of Writing Research. New York: The Guilford Press.

Graham, S., \& Sandmel, K. (2011). The process writing approach: A meta-analysis. The Journal of Educational Research, 104(6), 396. https://doi.org/10.1080/00220671.2010.488703

Jusun, K. D., \& Yunus, M. M. (2016). The effectiveness of using sentence makers in improving writing performance among pupils in Lubok Antu rural schools. Education and Innovation in Science in the Digital Era (pp. 469-475).

Karatay, H. (2011). The effect of 4+1 planned writing and evaluation model to develop the attitudes of preservice teachers as to written expression and their writing skills. Turkish Studies, 6(3), 1029-1047. https://doi.org/10.7827/TurkishStudies.2622

Kroll, B. (1990). Second language writing: Research insights for the classroom. Cambridge: Cambridge University Press. https://doi.org/10.1017/CBO9781139524551

Kroll B. 2001 The composition of a life in composition. In T. Silva, \& P. Matsuda (Eds.), On second language writing (pp.1-16). Mahwah, NJ: Erlbaum

Lau, K. W., \& Lee, P. Y. (2012). The use of virtual reality for creating unusual environmental stimulation to motivate students to explore creative ideas. Interactive Learning Environments, 23(1), 3-18. https://doi.org/10.1080/10494820.2012.745426

Lau, K. W., \& Lee, P. Y. (2015). The use of virtual reality for creating unusual environmental stimulation to motivate students to explore creative ideas. Interactive Learning Environments, 23(1), 3-18. https://doi.org/10.1080/10494820.2012.745426

Maghsoudi, M., \& Haririan, J. (2013). The impact of brainstorming strategies Iranian EFL learners writing skill regarding their social class status. Journal of language and linguistics, $\quad 1(1), \quad 60-67 . \quad$ Retrieved from http://dx.doi.org/10.11648/j.ijll.s.20130101.20.

Malaysia Ministry of Education (http://www.moe.gov.my).

Merriam, S. B. (1988). Case study researching education: A qualitative approach. San Francisco: Jossey-Bass.

Migawer. (2001). Teaching of Arabic language at secondary Stage (Its basis and educational applications). Egypt: Dar-Alfiker.

Nunan, D. (1991). Language teaching methodology: A textbook for teachers. Prentice Hall

Nunan, D. (2001). Second English teaching and learning. Beijing: Foreign language teaching and Research Press.

Rao, P. S. (2019). The significance of writing skills in ELL environment. ACADEMICIA: An International Multidisciplinary Journal, 9(3), 5-17. DOI: 10.5958/22497137.2019.00035.1

Rao, P. S. (2017a). The characteristics of effective writing skills in English language teaching. Research Journal of English, 2(2), 75-86.

Rao, P. S. (2017b). Developing writing skills among the EFL/ESL learners. Research Journal of English, 2(3), 52-63

Rao, P. S. (2019). The impact of English movies on learning English in ESL/EFL Classrooms. Research Journal of English Language and Literature (RJELAL), 7(4), 430-438. 
Rao, Z. (2007). Training in brainstorming and developing writing skills. ETL Journal, 61(2), 44-51. https://doi.org/10.1093/elt/ccm002

Richards, J. C., \& Renandya, W. A. (2002). Methodology in language teaching: An anthology of current practice. Cambridge: Cambridge University Press. https://doi.org/10.1017/CBO9780511667190

Richards, J. C., \& Renandya, W. A. (2010). Methodology in language teaching. Cambridge: CUP.

Richards, J. C., \& Schmidt, R. (2002). Language teaching and applied linguistics. Edinburgh: Pearson Education Limited.

Robson, C. (2002). Real world research (2nd Ed.). Oxford: Blackwell.

Saed, H. A., \& AL-Omari, H. A. (2014). The effectiveness of a proposed program based on a mind mapping strategy in developing the writing achievement of eleventh grade EFL students in Jordan and their attitudes towards writing. Journal of Education and Practice, 5, 88-109.

Steele, V. (1992). Product and process writing: A comparison. Rowley: Newbury House.

Steele, V. (2004). Product and process writing. Retrieved from http:// www.englishonline.org.cn/en/teachers/workshops/teaching-writing/teachingtips/product-process

Troyka, L. Q. (2010). Simon \& Schuster handbook for writers (5th Ed.). Toronto: Pearson Prentice Hall.

Yunus, M. M., \& Chien, C. H. (2016). The use of mind mapping strategy in Malaysian university English test (MUET) Writing. Creative Education, 7(4), 619-626. http://dx.doi.org/10.4236/ce.2016.74064

Yunus, M. M., \& Salehi, H. (2012). The effectiveness of Facebook groups on teaching and improving writing: Students' Perceptions. International Journal of Education and Information Technologies, 1(6), 87-96.

Zhao, J. (2017). Native speaker advantage in academic writing? Conjunctive realizations in EAP writing by four groups of writers. Ampersand, 4, 47-57. https://doi.org/10.1016/j.amper.2017.07.001 